\title{
Um código de condutas para o recrutamento internacional de profissionais de saúde: o manifesto de Melbourne
}

Adotado na 5 a Conferência Mundial de Saúde Rural da Wonca

Melbourne, Austrália, 3 de maio de 2002

WONCA Working Party on Rural Practice

\section{Preâmbulo}

Muitos países, tanto no mundo em desenvolvimento quanto desenvolvido, estão experimentando déficits de profissionais de saúde qualificados, especialmente em áreas rurais e de maior privação social.

Uma das respostas dos países mais ricos é o recrutamento de profissionais de saúde dos países mais pobres, em vez do treinamento suficiente de pessoas de seus próprios territórios.

Isto leva a um fluxo de profissionais altamente qualificados para fora dos países que menos podem se dar o luxo de perdê-los. O resultado é o impacto negativo nos sistemas de saúde já seriamente defasados e, consequentemente, uma piora no status de saúde destas nações.

O desenvolvimento de um código ético deve equilibrar os direitos dos indivíduos viajarem e as necessidades das comunidades.

\section{Princípios}

Nós afirmamos que:

1. É responsabilidade de cada país assegurar que esteja formando suficientemente profissionais de saúde para suas necessidades atuais e futuras; retendo-os; e realizando planejamento tanto para áreas rurais quanto urbanas.

2. O recrutamento internacional está relacionado a uma inabilidade de países em satisfazer suas próprias necessidades de recursos humanos.

3. Os princípios de justiça social e equidade global, a autonomia e liberdade individuais e os direitos das naçóes devem ser levados em consideração de forma equilibrada. 
4. Integridade, transparência e colaboração devem caracterizar qualquer recrutamento de recursos humanos em saúde.

5. Intercâmbios internacionais de profissionais de saúde são parte importante do desenvolvimento internacional do cuidado à saúde.

6. Países que produzem mais profissionais de saúde do que necessitam, podem continuar a contribuir para a saúde global.

\section{Proposta}

Este código de conduta objetiva:

- Promover os melhores padróes de qualidade possíveis no cuidado à saúde em todo o mundo;

- Encorajar o planejamento racional das forças de trabalho por todos os países, de forma a satisfazer suas próprias necessidades;

- Desencorajar atividades que possam causar dano a qualquer sistema de saúde nacional.

\section{Código}

Países, levando em conta e se beneficiando do recrutamento de outros países, devem:

a. Examinar sua própria situação nacional e

i. considerar os efeitos que suas políticas e práticas atuais de recrutamento estâo produzindo em países menos desenvolvidos;

ii. desenvolver e implementar suas próprias políticas éticas de recrutamento;

iii. assegurar que o número e distribuição de postos de treinamento de graduação e pós-graduação DISPONÍVEIS dentro do país estejam adequados e atendam às necessidades nacionais;

iv. assegurar que as condiçóes nacionais de trabalho e oportunidades educacionais sejam suficientes para encorajar profissionais de saúde a trabalhar nas áreas de necessidade;

v. desenvolver e apoiar ligação ativa educacional com universidades e escolas médicas em países menos desenvolvidos que contribuam para a educação e treinamento de seus profissionais de saúde;

vi. considerar meios alternativos e inovadores de prover cuidado à saúde em áreas necessárias tais como o desenvolvimento de equipes multidisciplinares e colaboração intersetorial;

vii. explorar o uso de habilidades dos profissionais de saúde que migraram por razóes pessoais e que estáo morando nesses países, mas impossibilitados de trabalhar.

b. Revisar suas estratégias de recrutamento e assegurar que elas:

i. Reconheçam os princípios presentes na Declaração de Durban da Wonca "Saúde para Toda População Rural" de 1997, juntamente com os princípios apontados acima;

ii. Desenvolver um Memorando de Entendimento (ME) com os países que deseja recrutar. Este ME deve destacar temas como:

- Como o recrutamento será realizado;

- Os benefícios para cada país; 
- A natureza e grau de compensação que deve ser empenhado para contribuir para o apoio e treinamento dos profissionais de saúde nos seus países de origem;

- As etapas requeridas para assegurar que qualquer recrutamento por agências ou governo seja conduzido e monitorado de acordo com este código de práticas;

- A inclusão de profissionais de saúde recrutados sob as leis trabalhistas do país receptor;

- A provisão de total e acurada informação aos potenciais recrutados a respeito da natureza do trabalho, procedimentos de seleção e direitos contratuais e obrigaçôes;

- O apoio, educação, treinamento e desenvolvimento profissional continuado posterior disponível para o recrutado de forma equivalente a qualquer outro profissional de saúde;

- O suporte e encorajamento do retorno dos profissionais a seus países de origem.

iii. Somente recrutar e divulgar (incluindo periódicos nacionais) de outro país quando um ME existir.

Países experimentando perda danosa de profissionais de saúde devem explorar as razões pelas quais os profissionais de saúde estão partindo e encarar estas da seguinte forma:

a. Avaliar seus próprios programas de treinamento para assegurar que eles equipem seus graduados com conhecimento, habilidades e atitudes que são mais apropriados para as necessidades nacionais;

b. Assegurar que as condiçôes de trabalho, incentivos e oportunidades educativas nos seus países sejam suficientes para encorajar os profissionais de saúde a trabalhar nas áreas de necessidade;

c. Considerar formas alternativas e inovadoras de prover cuidado à saúde em áreas necessárias como o desenvolvimento de equipes multidisciplinares e colaboração intersetorial.

Países em desenvolvimento devem receber suporte de países desenvolvidos para recrutar recursos humanos em saúde, visto que eles não estão aptos a competir em termos de pacotes de incentivo financeiro. Tais recrutamentos devem focar na provisão de oportunidades de curta duração para profissionais de saúde com habilidades clínicas, em educação, gestão e pesquisa, entre outras, para auxiliar no desenvolvimento dos serviços de saúde nesses países.

Os países devem desenvolver processos transparentes para o registro limitado ou licenciamento de profissionais de saúde treinados no exterior que permitam:

a. Intercâmbio de curta duração, fellowships, períodos de licença, que podem:

i. Oferecer oportunidades de aprimoramento prático e experiência dentro de um período específico;

ii. Permitir pessoal treinado dos países que recrutam de se beneficiar de experiências de intercâmbio no exterior.

b. Treinamento posterior para profissionais de saúde de países em desenvolvimento em países mais desenvolvidos. Isto pode gerar uma contribuiçáo positiva se for estruturado de forma a garantir o retorno de profissionais de saúde para seus países de origem após o treinamento, ao menos pelo período equivalente ao da duraçáo do treinamento;

c. Mobilidade internacional de profissionais de saúde preparados para trabalhar em áreas de grande necessidade.

Nós acreditamos que deve haver um processo internacional para assegurar a avaliação e monitoramento contínuo da migração internacional de recursos humanos em saúde para atualizar este código.

Os participantes da 5a Conferência Mundial de Saúde Rural em Melbourne, desta forma, conclamam todos os países a adotar este Código de Condutas para o Recrutamento Internacional de Profissionais de Saúde.

Tradução para a versão brasileira: Leonardo Vieira Targa

Revisão: André L. Silva

Rio de Janeiro: SBMFC, 2011. 